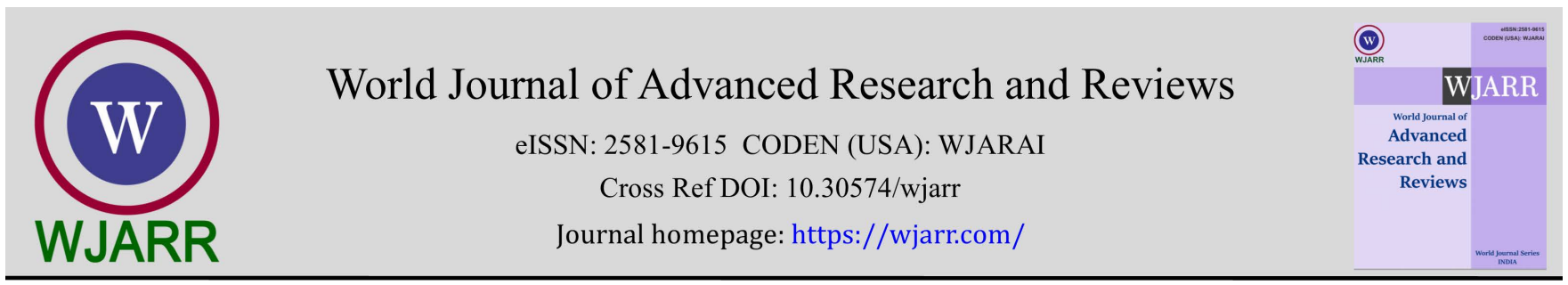

(RESEARCH ARTiClE)

\title{
Crop water and irrigation requirements of some selected crops in southwestern hydrological zone of Nigeria
}

\author{
GA Ali $1{ }^{*}$, TA Ademiju ${ }^{2}$ and JA Osunbitan ${ }^{3}$ \\ ${ }^{1}$ Department of Agricultural \& Bio- Environmental Engineering Technology, Federal Polytechnic, Ede, Nigeria. \\ 2 Department of Agricultural Education, Federal College of Education (Technical), Asaba, Nigeria. \\ ${ }^{3}$ Department of Agricultural and Environmental Engineering, Faculty of Technology, Obafemi Awolowo University, Ile - \\ Ife. Nigeria.
}

World Journal of Advanced Research and Reviews, 2021, 12(01), 117-125

Publication history: Received on 02 August 2021; revised on 30 September 2021; accepted on 02 October 2021

Article DOI: https://doi.org/10.30574/wjarr.2021.12.1.0416

\begin{abstract}
This study was carried out to determine the crop water and irrigation requirement of some selected crops in southwestern Nigeria. The crops are cucumber, water melon, maize, groundnut, eggplant and tomato. Irrigation requirement and crop coefficient for each crops were determined from the interrelationships of the evapotranspiration, soil type, bulk density, field capacity and the effective root zone of the crops at the selected locations using CROPWAT for windows version 8. Soil parameters used for analysis were determined from laboratory experiment. The crop evapotranspiration and water requirement for cucumber varied from 2.52 to $7.21 \mathrm{~mm} / \mathrm{day}$ and 17 to $73.2 \mathrm{~mm} / \mathrm{dec}$, respectively, for maize from 1.36 to $6.35 \mathrm{~mm} /$ day and 5.1 to $63.5 \mathrm{~mm} / \mathrm{dec}$ respectively, for watermelon varied from 2.59 to $6.67 \mathrm{~mm} /$ day and 25.9 to $73.3 \mathrm{~mm} / \mathrm{dec}$ respectively, for eggplant varied from 1.92 to $6.35 \mathrm{~mm} /$ day and 15.9 to $64.4 \mathrm{~mm} / \mathrm{dec}$ respectively. The irrigation requirement for water melon and cucumber recorded the highest value of 461.6 and $497.4 \mathrm{~mm} / \mathrm{dec}$ respectively, an indication that the two crops require more water for physiological activities. The reduction in the values of crop coefficient was observed during the study which could be attributed to the reduction in evapotranspiration at the late stage of growth. The findings also showed that known quantities of irrigation water could be used in producing crops optimally.
\end{abstract}

Keywords: Crop water requirement; Evapotranspiration; Irrigation requirement; Reference evapotranspiration; Peak water requirement and crop coefficient

\section{Introduction}

Irrigation development has risen to become one of the most commonly practiced strategy to secure food self sufficiency. It is a process of supplying water, in addition to natural precipitation to field crops or other cultivated plants. The role of irrigation is to improve production and the effectiveness of other inputs. Overall, irrigation water is applied to maintain a favourable water balance in the crop root zone, but, in order to maintain this balance, an excess of water is applied resulting in some water becoming deep percolated or surface runoff (7). The primary objective of irrigation water is to maintain crop evapotranspiration $\left(\mathrm{ET}_{\mathrm{c}}\right)$ when precipitation is insufficient. The amount of water required to compensate the evapotranspiration loss from the cropped field is defined as crop water requirement. Although the values for Crop evapotranspiration under standard conditions (ETc) and crop water requirement are identical, crop water requirement refers to the amount of water that needs to be supplied, while crop evapotranspiration refers to the amount of water that is lost through evapotranspiration (5). Crop evapotranspiration can be calculated from climatic data and by integrating directly the crop resistance, albedo and air resistance factors in the Penman-Monteith approach.

\footnotetext{
${ }^{*}$ Corresponding author: GA Ali

Dept. of Agricultural \& Bio- Environmental Engineering Technology, Federal Polytechnic, Ede, Nigeria.

Copyright (@ 2021 Author(s) retain the copyright of this article. This article is published under the terms of the Creative Commons Attribution Liscense 4.0.
} 
CROPWAT is meant as a practical tool to carry out standard calculations for reference evapotranspiration, crop water requirements and crop irrigation requirements, and more specifically the design and management of irrigation schemes $(3,1,5)$. It allows the development of recommendations for improved irrigation practices, the planning of irrigation schedules under varying water supply conditions, and the assessment of production under rainfed conditions or deficit irrigation. Water requirement depend mainly on environmental conditions, however, different crops have different water use requirements, under the same weather conditions (1). The importance of knowing seasonal crop water requirement cannot be overemphasized as is crucial in planning crop planting during dry season farming (2). Typically, this is most often determined by farmer's judgment or using a pre-determined method of irrigation events based on previous seasons' water requirements. Several factors such as plant evaporative demand, soil characteristics and root distribution are not taken into consideration as well, in order to establish proper irrigation scheduling.

The importance of irrigation scheduling is that it enables the irrigator to apply the exact amount of water to achieve the goal and this increases irrigation efficiency (10). This study endeavoured to estimate crop water and irrigation requirements of some crops in selected farms in Ogun-Osun River Basin with a view to improve the productivity and crop yield.

\section{Material and methods}

The study was carried out in some selected farms in Ogun-Osun River Basin. The basin covers Osun, Oyo, Ogun and Lagos states of Nigeria. It has an estimated land area of $66264 \mathrm{~km}^{2}$ which is drained by two main rivers, the Ogun and Osun rivers (after which the River Basin is named) (8). One irrigation project was selected each from Oyo and Ogun States (Figures 1) namely Sepeteri and Oke-Odan irrigation project for the study. The criteria for consideration of the two irrigation projects were based on the availability of agro-climatic data and organizational set up of the irrigation projects. From the two (2) irrigation projects, four (4) farms were randomly selected each from the scheme.

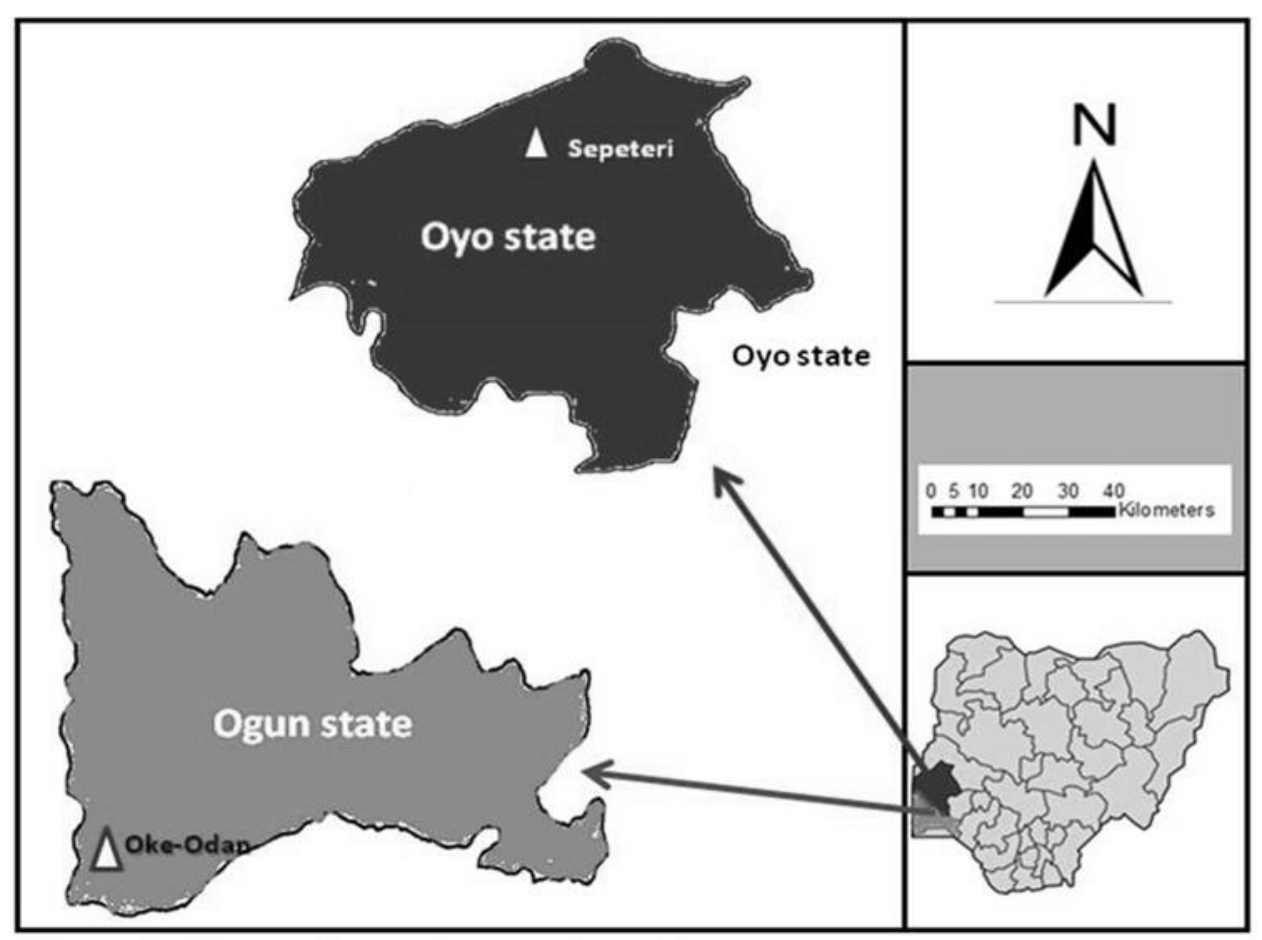

Figure 1 Map of Nigeria showing the study area

The Sepeteri Irrigation Project is located near Saki (Altitude-347m, lat $8.83^{\circ} \mathrm{N}$, Long. $3.39{ }^{0} \mathrm{E}$ ), in the Saki-East Local Government area of Oyo State (Figure 1). The scheme has 2 diesel engine pumps with an average discharge of 8.5 litres per seconds. Abstraction is predominantly by pumping using diesel engines. Solid set sprinkler irrigation was being practiced as at the time of the survey but installation of centre pivot system was on-going. The project occupied 2,000 ha (400 ha developed) of land with 25 ha under irrigation. The main crops grown in the irrigation project are tomato, maize, water melon, groundnut and cucumber, while Oke-Odan irrigation scheme (Figure 1) is located in Yewa North Local Government of Ogun state (Altitude-35m, lat $6.42^{\circ} \mathrm{N}$, Long. $2.54{ }^{\circ} \mathrm{E}$ ); it occupies 400 ha irrigable land with one dam 
which has not been fully utilized since the inception of the project. Abstraction is predominantly by pumping using diesel engines. A centre pivot irrigation system is used to irrigate crops in the scheme. The main crops grown in the scheme are water melon, Cucumber, Maize and Egg plant.

\subsection{Determination of crop water requirement}

Calculations of the crop water and irrigation requirements are carried out using CROPWAT version 8 (CROPWAT is a decision support system for planning and management of irrigation) with inputs of climatic, crop and soil data. The climatic data used for the calculations were obtained from Nigerian Meteorological Agency (NIMET). Crop water requirement was determined from the interrelationships of the ET, soil type, bulk density of the soil, field capacity and permanent wilting point of the soil and the effective root zone of the crops at the selected locations.

The model calculates the Crop Water Requirements using the equation:

$\mathrm{CWR}=\mathrm{ET}_{\mathrm{o}} * \mathrm{~K}_{\mathrm{c}} *$ area planted

where $\mathrm{ET}_{\mathrm{o}}$ as estimated by FAO Penman-Monteith equation (FAO, 1992 and Smith et al., 1991)

$\mathrm{ET}_{\mathrm{o}}=\mathrm{ET}_{\mathrm{c}}=\mathrm{K}_{\mathrm{c}}\left(\mathrm{ET}_{\mathrm{o}}\right)$

Reference evapotranspiration $\left(\mathrm{ET}_{\mathrm{o}}\right)$ is defined as follow:

$\mathrm{ET}_{\mathrm{o}}=\frac{0.408 \Delta\left(\mathrm{R}_{\mathrm{n}}-\mathrm{G}\right)+\gamma \frac{900}{\mathrm{~T}+273} \mathrm{u}_{2}\left(\mathrm{e}_{\mathrm{s}}-\mathrm{e}_{\mathrm{a}}\right)}{\Delta+\gamma\left(1+0.34 \mathrm{u}_{2}\right)}$

Where:

$\mathrm{ET}_{\mathrm{o}}=$ Reference evapotranspiration $(\mathrm{mm} /$ day $)$

$\mathrm{R}_{\mathrm{n}}=$ Net radiation at the crop surface $(\mathrm{MJ} / \mathrm{m} 2$ per day)

$\mathrm{G}=$ Soil heat flux density $(\mathrm{MJ} / \mathrm{m} 2$ per day)

$\mathrm{T}=$ Mean daily air temperature at $2 \mathrm{~m}$ height $\left({ }^{\circ} \mathrm{C}\right)$

$\mathrm{u}_{2}=$ Wind speed at $2 \mathrm{~m}$ height $(\mathrm{m} / \mathrm{sec})$

$\mathrm{e}_{\mathrm{s}}=$ Saturation vapour pressure $(\mathrm{kPa})$

$\mathrm{e}_{\mathrm{a}}=$ Actual vapour pressure $(\mathrm{kPa})$

$\mathrm{e}_{\mathrm{s}}-\mathrm{e}_{\mathrm{a}}=$ Saturation vapour pressure deficit $(\mathrm{kPa})$

The average values of crop coefficient for each time step are estimated by linear interpolation between the $\mathrm{K}_{\mathrm{c}}$ values for each crop development stage. The Crop Kc values are calculated as:

$\mathrm{K}_{\mathrm{c}}$ * Crop Area, if the crop covers only $50 \%$ of the area, the Crop $\mathrm{K}_{\mathrm{c}}$ values will be half of the $\mathrm{K}_{\mathrm{c}}$ values in the crop coefficient data file $(5,9)$. For crop water requirements and scheduling purposes, the monthly total rainfall has to be distributed into equivalent daily values (4).

\section{Results and discussion}

Tables 1, 2, 3 and 4 depict crop water requirement for water melon, maize, groundnut, and tomato, respectively from farms in Sepeteri irrigation scheme. The results showed that for water melon, crop evapotranspiration (ET $\mathrm{Crop}_{\text {) }}$ and Crop Water Requirement (CWR) varied from 2.59 to $5.09 \mathrm{~mm} /$ day and 18 to $50.9 \mathrm{~mm} / \mathrm{dec}$, respectively (Table 1). For Maize, $\mathrm{ET}_{\text {crop }}$ and CWR varied from 1.36 to $5.14 \mathrm{~mm} /$ day and 1.1 to $51.4 \mathrm{~mm} / \mathrm{dec}$, respectively (Table 3). For Groundnut, crop evapotranspiration (ET $\mathrm{Erop}_{\text {) }}$ and crop water requirement for varied from 1.77 to $5.5 \mathrm{~mm} /$ day and 5.0 to $55 \mathrm{~mm} / \mathrm{dec}$,

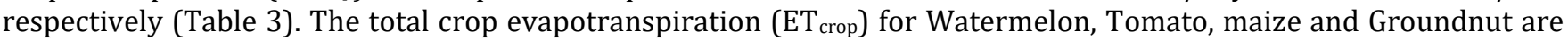
$564.1,426.5,423.1$ and $484.1 \mathrm{~mm} / \mathrm{dec}$ respectively (Table 4 and Table 5). From Table 1, irrigation requirement for 
watermelon was $422.9 \mathrm{~mm} / \mathrm{dec}$. The finding from this research agrees with the observation of (1), who reported irrigation requirement value of $420.1 \mathrm{~mm} / \mathrm{dec}$ for water melon in a similar study. The values for other crops fall in the same range. (6) reported that crops grown in the dry season needs more water than those grown during rainy season.

Table 1 Evapotranspiration and Irrigation requirement for Water melon in Sepeteri

\begin{tabular}{|l|c|l|c|c|c|c|c|}
\hline Month & Decade & Stage & $\begin{array}{c}\text { Kc } \\
\text { Coeff }\end{array}$ & $\begin{array}{c}\text { Etc } \\
\mathbf{m m} / \mathbf{d a y}\end{array}$ & $\begin{array}{c}\text { Etc } \\
\mathbf{m m} / \mathbf{d e c}\end{array}$ & $\begin{array}{c}\text { Eff rain } \\
\mathbf{m m} / \mathbf{d e c}\end{array}$ & $\begin{array}{c}\text { Irr. Req. } \\
\mathbf{m m} / \mathbf{d e c}\end{array}$ \\
\hline Sep & 2 & Init & 0.6 & 2.59 & 10.4 & 15.1 & 0 \\
\hline Sep & 3 & Init & 0.6 & 2.66 & 26.6 & 41.6 & 0 \\
\hline Oct & 1 & Init & 0.6 & 2.73 & 27.3 & 51.7 & 0 \\
\hline Oct & 2 & Deve & 0.61 & 2.86 & 28.6 & 57.7 & 0 \\
\hline Oct & 3 & Deve & 0.73 & 3.46 & 38.1 & 38.5 & 0 \\
\hline Nov & 1 & Deve & 0.86 & 4.24 & 42.4 & 0.1 & 42.3 \\
\hline Nov & 2 & Deve & 0.99 & 5 & 50 & 0 & 50 \\
\hline Nov & 3 & Mid & 1.1 & 5.09 & 50.9 & 0 & 50.9 \\
\hline Dec & 1 & Mid & 1.11 & 4.59 & 45.9 & 0 & 45.9 \\
\hline Dec & 2 & Mid & 1.11 & 4.13 & 41.3 & 0 & 41.3 \\
\hline Dec & 3 & Mid & 1.11 & 4.22 & 46.4 & 0 & 46.4 \\
\hline Jan & 1 & Late & 1.11 & 4.26 & 42.6 & 0 & 42.6 \\
\hline Jan & 2 & Late & 1.03 & 3.98 & 39.8 & 0 & 39.8 \\
\hline Jan & 3 & Late & 0.91 & 3.93 & 43.2 & 0.1 & 43.1 \\
\hline Feb & 1 & Late & 0.8 & 3.84 & 30.8 & 10.2 & 20.6 \\
\hline Total & & & & & 564.1 & 215 & 422.9 \\
\hline
\end{tabular}

Table 2 Evapotranspiration and Irrigation requirement for Maize in Sepeteri

\begin{tabular}{|l|c|l|c|c|c|c|c|}
\hline Month & Decade & Stage & $\begin{array}{c}\text { Kc } \\
\text { Coeff }\end{array}$ & $\begin{array}{c}\text { Etc } \\
\mathbf{m m} / \mathbf{d a y}\end{array}$ & $\begin{array}{c}\text { Etc } \\
\mathbf{m m} / \mathbf{d e c}\end{array}$ & $\begin{array}{c}\text { Eff rain } \\
\mathbf{m m} / \mathbf{d e c}\end{array}$ & $\begin{array}{c}\text { Irr. Req. } \\
\mathbf{m m} / \mathbf{d e c}\end{array}$ \\
\hline Oct & 1 & Init & 0.3 & 1.36 & 10.9 & 41.3 & 0 \\
\hline Oct & 2 & Init & 0.3 & 1.4 & 14 & 57.7 & 0 \\
\hline Oct & 3 & Deve & 0.4 & 1.9 & 20.9 & 38.5 & 0 \\
\hline Nov & 1 & Deve & 0.65 & 3.2 & 32 & 0.1 & 31.9 \\
\hline Nov & 2 & Deve & 0.89 & 4.5 & 45 & 0 & 45 \\
\hline Nov & 3 & Mid & 1.11 & 5.14 & 51.4 & 0 & 51.4 \\
\hline Dec & 1 & Mid & 1.14 & 4.73 & 47.3 & 0 & 47.3 \\
\hline Dec & 2 & Mid & 1.14 & 4.26 & 42.6 & 0 & 42.6 \\
\hline Dec & 3 & Mid & 1.14 & 4.34 & 47.8 & 0 & 47.8 \\
\hline Jan & 1 & Late & 1.11 & 4.24 & 42.4 & 0 & 42.4 \\
\hline Jan & 2 & Late & 0.87 & 3.34 & 33.4 & 0 & 33.4 \\
\hline Jan & 3 & Late & 0.59 & 2.54 & 28 & 0.1 & 27.9 \\
\hline Feb & 1 & Late & 0.39 & 1.88 & 7.5 & 5.1 & 2.4 \\
\hline Total & & & & & 423.1 & 142.9 & 372.1 \\
\hline
\end{tabular}


Table 3 Evapotranspiration and Irrigation requirement for Groundnut in Sepeteri

\begin{tabular}{|l|c|l|c|c|c|c|c|}
\hline Month & Decade & Stage & $\begin{array}{c}\text { Kc } \\
\mathbf{c o e f f}\end{array}$ & $\begin{array}{c}\text { Etc } \\
\mathbf{m m} / \mathbf{d a y}\end{array}$ & $\begin{array}{c}\text { ETc } \\
\mathbf{m m} / \mathbf{d e c}\end{array}$ & $\begin{array}{c}\text { Eff rain } \\
\mathbf{m m} / \mathbf{d e c}\end{array}$ & $\begin{array}{c}\text { Irr. Req. } \\
\mathbf{m m} / \mathbf{d e c}\end{array}$ \\
\hline Sep & 3 & Init & 0.4 & 1.77 & 8.9 & 20.8 & 0 \\
\hline Oct & 1 & Init & 0.4 & 1.82 & 18.2 & 51.7 & 0 \\
\hline Oct & 2 & Init & 0.4 & 1.87 & 18.7 & 57.7 & 0 \\
\hline Oct & 3 & Deve & 0.54 & 2.56 & 28.1 & 38.5 & 0 \\
\hline Nov & 1 & Deve & 0.78 & 3.82 & 38.2 & 0.1 & 38.1 \\
\hline Nov & 2 & Deve & 1.01 & 5.08 & 50.8 & 0 & 50.8 \\
\hline Nov & 3 & Mid & 1.19 & 5.5 & 55 & 0 & 55 \\
\hline Dec & 1 & Mid & 1.2 & 4.96 & 49.6 & 0 & 49.6 \\
\hline Dec & 2 & Mid & 1.2 & 4.47 & 44.7 & 0 & 44.7 \\
\hline Dec & 3 & Mid & 1.2 & 4.56 & 50.1 & 0 & 50.1 \\
\hline Jan & 1 & Late & 1.19 & 4.58 & 45.8 & 0 & 45.8 \\
\hline Jan & 2 & Late & 0.99 & 3.81 & 38.1 & 0 & 38.1 \\
\hline Jan & 3 & Late & 0.7 & 3.01 & 33.1 & 0.1 & 33 \\
\hline Feb & 1 & Late & 0.51 & 2.48 & 5 & 2.6 & 2.4 \\
\hline Total & & & & & 484.1 & 171.5 & 407.5 \\
\hline
\end{tabular}

Table 4 Evapotranspiration and Irrigation requirement for Tomato in Sepeteri

\begin{tabular}{|c|c|c|c|c|c|c|c|}
\hline Month & Decade & Stage & $\begin{array}{c}\text { Kc } \\
\text { Coeff }\end{array}$ & ETc mm/day & ETc mm/dec & Eff rain $\mathrm{mm} / \mathrm{dec}$ & $\begin{array}{l}\text { Irr.Req. } \\
\text { mm/dec }\end{array}$ \\
\hline Nov & 1 & Init & 0.50 & 2.46 & 22.1 & 0.1 & 22.0 \\
\hline Nov & 2 & Init & 0.50 & 2.52 & 25.2 & 0.0 & 25.2 \\
\hline Nov & 3 & Deve & 0.51 & 2.39 & 23.9 & 0.0 & 23.9 \\
\hline Dec & 1 & Deve & 0.64 & 2.64 & 26.4 & 0.0 & 26.4 \\
\hline Dec & 2 & Deve & 0.78 & 2.92 & 29.2 & 0.0 & 29.2 \\
\hline Dec & 3 & Deve & 0.94 & 3.56 & 39.2 & 0.0 & 39.2 \\
\hline Jan & 1 & Mid & 1.01 & 3.88 & 38.8 & 0.0 & 38.8 \\
\hline Jan & 2 & Mid & 1.01 & 3.89 & 38.9 & 0.0 & 38.9 \\
\hline Jan & 3 & Mid & 1.01 & 4.37 & 48.1 & 0.1 & 48.0 \\
\hline Feb & 1 & Late & 1.01 & 4.87 & 48.7 & 12.8 & 35.9 \\
\hline Feb & 2 & Late & 0.91 & 4.78 & 47.8 & 19.2 & 28.6 \\
\hline Feb & 3 & Late & 0.77 & 4.26 & 34.1 & 16.9 & 17.2 \\
\hline Mar & 1 & Late & 0.70 & 4.11 & 4.1 & 1.2 & 2.9 \\
\hline Total & & & & & 426.5 & 50.4 & 376.2 \\
\hline
\end{tabular}


Table 5 Summary of Evapotranspiration and Irrigation water requirement for Crops in Sepeteri irrigation project

\begin{tabular}{|l|c|c|c|}
\hline Crop & $\begin{array}{l}\text { ET } \\
\text { (mm/dec) }\end{array}$ & $\begin{array}{l}\text { Eff rain } \\
\text { (mm/dec) }\end{array}$ & $\begin{array}{l}\text { Irr. Req. } \\
\text { (mm/dec) }\end{array}$ \\
\hline Maize & 423.1 & 142.9 & 372.1 \\
\hline Groundnut & 484.1 & 171.5 & 407.5 \\
\hline Tomato & 426.5 & 50.4 & 376.2 \\
\hline Water Melon & 564.1 & 215.0 & 422.9 \\
\hline
\end{tabular}

\section{Crop water requirements of selected farms in Oke-Odan irrigation scheme}

The crop evapotranspiration ( $\mathrm{ET}_{\mathrm{crop}}$ ) and crop water requirement for Cucumber varied from 2.52 to $7.21 \mathrm{~mm} / \mathrm{day}$ and 17 to $73.2 \mathrm{~mm} / \mathrm{dec}$, respectively (Table 6).

Table 6 Evapotranspiration and Irrigation requirement for Cucumber in Oke-odan

\begin{tabular}{|l|c|l|c|c|c|c|c|}
\hline Month & Decade & Stage & Kc & Etc & Etc & Eff rain & Irr. Req. \\
\hline & & & Coeff & $\mathbf{m m} / \mathbf{d a y}$ & $\mathbf{m m} / \mathbf{d e c}$ & $\mathbf{m m / d e c}$ & $\mathbf{m m} / \mathbf{d e c}$ \\
\hline Nov & 1 & Init & 0.5 & 2.52 & 25.2 & 6.8 & 18.4 \\
\hline Nov & 2 & Deve & 0.71 & 3.52 & 35.2 & 0 & 35.2 \\
\hline Nov & 3 & Deve & 1.08 & 5.6 & 56 & 0 & 56 \\
\hline Dec & 1 & Mid & 1.25 & 6.89 & 68.9 & 0.1 & 68.8 \\
\hline Dec & 2 & Mid & 1.25 & 7.21 & 72.1 & 0 & 72.1 \\
\hline Dec & 3 & Mid & 1.25 & 6.65 & 73.2 & 0 & 73.2 \\
\hline Jan & 1 & Late & 1.25 & 5.74 & 57.4 & 0 & 57.4 \\
\hline Jan & 2 & Late & 1.14 & 4.7 & 47 & 0 & 47 \\
\hline Jan & 3 & Late & 0.97 & 4.46 & 49.1 & 0.1 & 49 \\
\hline Feb & 1 & Late & 0.81 & 4.21 & 33.7 & 13.4 & 20.3 \\
\hline Total & & & & & 517.9 & 20.5 & 497.4 \\
\hline
\end{tabular}

Table 7 Evapotranspiration and Irrigation requirement for Maize in Oke-odan

\begin{tabular}{|l|c|l|c|c|c|c|c|}
\hline Month & Decade & Stage & Kc & Etc & Etc & Eff rain & Irr. Req. \\
\hline Sep & & & Coeff & $\mathbf{m m / d a y}$ & $\mathbf{m m} / \mathbf{d e c}$ & $\mathbf{m m / d e c}$ & $\mathbf{m m} / \mathbf{d e c}$ \\
\hline Oct & 1 & Init & 0.3 & 1.36 & 13.6 & 54.8 & 0 \\
\hline Oct & 2 & Deve & 0.43 & 2.24 & 22.4 & 56.8 & 0 \\
\hline Oct & 3 & Deve & 0.67 & 3.45 & 37.9 & 38.6 & 0 \\
\hline Nov & 1 & Deve & 0.91 & 4.57 & 45.7 & 6.8 & 38.9 \\
\hline Nov & 2 & Mid & 1.09 & 5.42 & 54.2 & 0 & 54.2 \\
\hline Nov & 3 & Mid & 1.1 & 5.7 & 57 & 0 & 57 \\
\hline Dec & 1 & Mid & 1.1 & 6.06 & 60.6 & 0.1 & 60.5 \\
\hline Dec & 2 & Mid & 1.1 & 6.35 & 63.5 & 0 & 63.5 \\
\hline Dec & 3 & Late & 1.04 & 5.51 & 60.6 & 0 & 60.6 \\
\hline Jan & 1 & Late & 0.79 & 3.62 & 36.2 & 0 & 36.2 \\
\hline Jan & 2 & Late & 0.54 & 2.21 & 22.1 & 0 & 22.1 \\
\hline Jan & 3 & Late & 0.38 & 1.73 & 5.2 & 0 & 5.2 \\
\hline Total & & & & & 494 & 212.2 & 398.2 \\
\hline
\end{tabular}


For Maize, crop evapotranspiration (ET $\mathrm{Erop}_{\text {) }}$ and crop water requirement varied from 1.36 to $6.35 \mathrm{~mm} / \mathrm{day}$ and 5.1 to $63.5 \mathrm{~mm} / \mathrm{dec}$ respectively (Table 7). For Watermelon, crop evapotranspiration (ET crop$_{\text {) }}$ and crop water requirement varied from 2.59 to $6.67 \mathrm{~mm} /$ day and 25.9 to 73.3 respectively (Table 8). The crop evapotranspiration (ET $\mathrm{Erop}_{\mathrm{c}}$ ) and crop water requirement for Eggplant varied from 1.92 to $6.35 \mathrm{~mm}$ /day and 15.9 to 64.4 respectively (Table 9). The irrigation requirement for Water melon and cucumber recorded the highest value of 461.6 and $497.4 \mathrm{~mm} / \mathrm{dec}$ respectively (Table 10 ), an indication that the two crops require more water for physiological activities.

Table 8 Evapotranspiration and Irrigation requirement for Water melon in Oke-odan

\begin{tabular}{|l|c|l|c|c|c|c|c|}
\hline Month & Decade & Stage & Kc & Etc & ETc & Eff rain & Irr. Req. \\
\hline & & & Coeff & $\mathbf{m m / d a y}$ & $\mathbf{m m} / \mathbf{d e c}$ & $\mathbf{m m / d e c}$ & $\mathbf{m m} / \mathbf{d e c}$ \\
\hline Nov & 3 & Init & 0.5 & 2.59 & 25.9 & 0 & 25.9 \\
\hline Dec & 1 & Deve & 0.71 & 3.9 & 39 & 0.1 & 38.9 \\
\hline Dec & 2 & Deve & 1.08 & 6.25 & 62.5 & 0 & 62.5 \\
\hline Dec & 3 & Mid & 1.25 & 6.67 & 73.3 & 0 & 73.3 \\
\hline Jan & 1 & Mid & 1.25 & 5.77 & 57.7 & 0 & 57.7 \\
\hline Jan & 2 & Mid & 1.25 & 5.16 & 51.6 & 0 & 51.6 \\
\hline Jan & 3 & Late & 1.25 & 5.76 & 63.3 & 0.1 & 63.2 \\
\hline Feb & 1 & Late & 1.13 & 5.86 & 58.6 & 16.7 & 41.9 \\
\hline Feb & 2 & Late & 0.95 & 5.34 & 53.4 & 25.1 & 28.3 \\
\hline Feb & 3 & Late & 0.8 & 4.63 & 37.1 & 18.8 & 18.3 \\
\hline Total & & & & & 522.4 & 61 & 461.6 \\
\hline
\end{tabular}

Table 9 Evapotranspiration and Irrigation requirement for egg plant in Oke-odan

\begin{tabular}{|l|c|l|c|c|c|c|c|}
\hline Month & Decade & Stage & Kc & Etc & ETc & Eff rain & Irr. Req. \\
\hline & & & coeff & $\mathbf{m m} / \mathbf{d a y}$ & $\mathbf{m m} / \mathbf{d e c}$ & $\mathbf{m m / d e c}$ & $\mathbf{m m} / \mathbf{d e c}$ \\
\hline Oct & 2 & Init & 0.4 & 2.11 & 10.5 & 28.4 & 0 \\
\hline Oct & 3 & Init & 0.4 & 2.07 & 22.8 & 38.6 & 0 \\
\hline Nov & 1 & Deve & 0.45 & 2.27 & 22.7 & 6.8 & 15.9 \\
\hline Nov & 2 & Deve & 0.67 & 3.34 & 33.4 & 0 & 33.4 \\
\hline Nov & 3 & Deve & 0.9 & 4.68 & 46.8 & 0 & 46.8 \\
\hline Dec & 1 & Mid & 1.09 & 5.99 & 59.9 & 0.1 & 59.8 \\
\hline Dec & 2 & Mid & 1.1 & 6.35 & 63.5 & 0 & 63.5 \\
\hline Dec & 3 & Mid & 1.1 & 5.86 & 64.4 & 0 & 64.4 \\
\hline Jan & 1 & Mid & 1.1 & 5.07 & 50.7 & 0 & 50.7 \\
\hline Jan & 2 & Late & 1 & 4.1 & 41 & 0 & 41 \\
\hline Jan & 3 & Late & 0.61 & 2.82 & 31.1 & 0.1 & 31 \\
\hline Feb & 1 & Late & 0.37 & 1.92 & 3.8 & 3.3 & 0.5 \\
\hline Total & & & & & 450.5 & 77.4 & 407.0 \\
\hline
\end{tabular}


Table 10 Summary of Evapotranspiration and Irrigation water requirement for Crops in Oke-Odan irrigation project

\begin{tabular}{|c|c|c|c|}
\hline Crop & $\begin{array}{c}\mathrm{ET}_{\mathrm{c}} \\
(\mathrm{mm} / \mathrm{dec})\end{array}$ & $\begin{array}{c}\text { Eff rain } \\
(\mathrm{mm} / \mathrm{dec})\end{array}$ & $\begin{array}{l}\text { Irr. Req. } \\
\text { (mm/dec) }\end{array}$ \\
\hline Maize & 494 & 212.2 & 398.2 \\
\hline Cucumber & 517.9 & 20.5 & 497.4 \\
\hline Water Melon & 522.4 & 61.0 & 461.6 \\
\hline Egg Plant & 450.5 & 77.4 & 407.0 \\
\hline
\end{tabular}

\section{Crop Coefficients $\left(K_{c}\right)$}

The crop coefficient $\left(\mathrm{K}_{\mathrm{c}}\right)$ relating water requirements $\left(\mathrm{ET}_{\mathrm{m}}\right)$ to reference evapotranspiration (ETo) for different crop growth stages in Sepeteri and Oke-Odan Irrigation schemes are shown in Figures 2 and 3, respectively. The crop coefficient varies according to the growth stages of the crop. The results obtained from the experimental data were compared with corresponding values of the FA0-56 Bulletin.

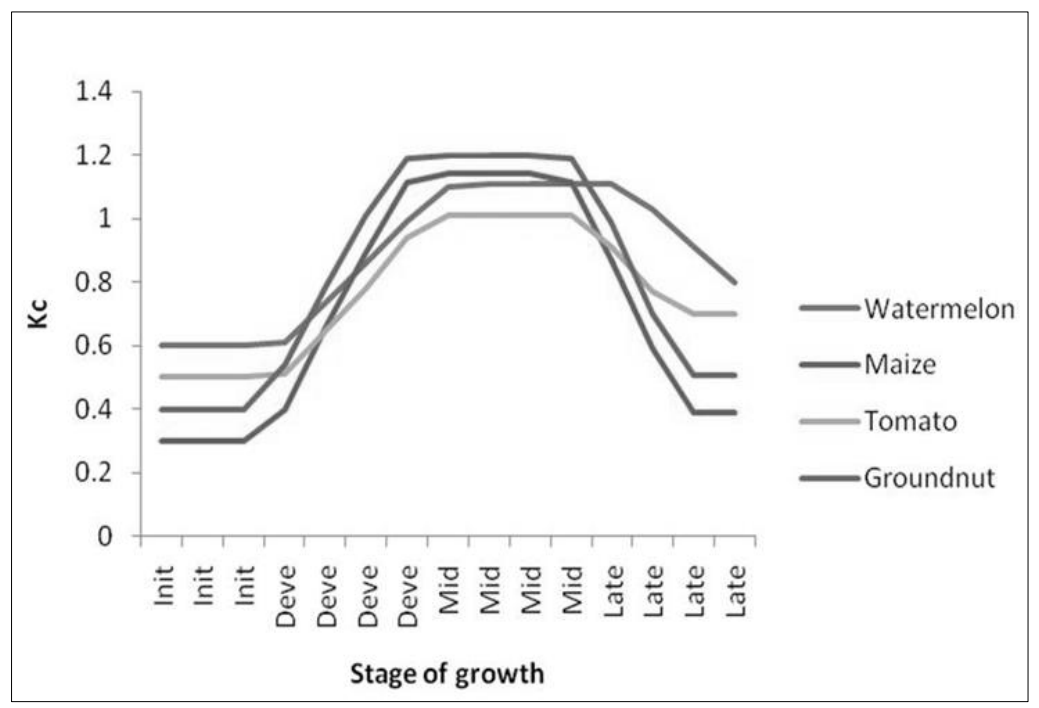

Figure 2 Crop Coefficients (Kc) in Sepeteri Irrigation scheme relating Stage of growth and water requirement

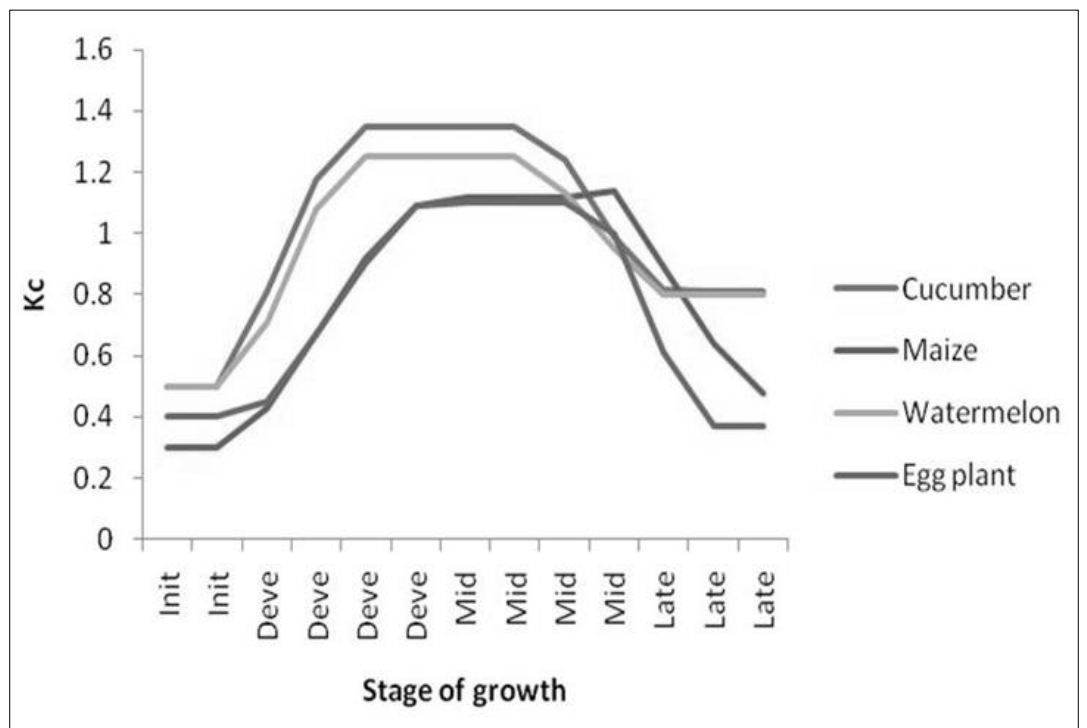

Figure 3 Crop Coefficients (Kc) in Oke-Odan Irrigation scheme relating Stage of growth and water requirement 
In Sepeteri Irrigation Scheme (Figure 2), the $\mathrm{K}_{\mathrm{c}}$ of Maize was 0.3 at the initial stage, the development stage (0.4 - 0.89), the mid-season stage $(1.11$ - 1.14) and during the late season stage (1.11 - 0.39). It can be deduced from the Figures 2 and 3 that water consumption by crops reach their peak during the mid-season stage. The crop type has an influence on the duration of the total growing season of the crop. Figure 3 shows the influence of the crop type and growth stage on crop water needs. For $\mathrm{K}_{\mathrm{c}}$ of Maize in Oke-Odan, initial stage of 0.3 , the development stage (0.43 - 0.91), the mid-season stage $(1.09-1.1)$ and during the late season stage $(1.04-0.38)$ was recorded. The reduction in the values of $K_{c}$ was attributed to the reduction in evapotranspiration at the late stage of growth.

\section{Conclusion}

The study indicates that the reserviour in the schemes can conveniently supply water required by the crops. Based on this water was not a constraint in the schemes. The results of the finding can serve as a guide for the participating farmers in the irrigation projects on when to irrigate in order to avoid stressing the crop. The findings also showed that known quantities of irrigation water could be used in producing crops optimally. The highest amount of soil water extraction took place at the mid-season/reproductive stage. This was as a result of increase in metabolic activities at that stage and hence greater consumptive water use. The irrigation requirement for water melon and cucumber was the highest which indicates that these crops use more water for its physiological activities.

\section{Compliance with ethical standards}

\section{Acknowledgments}

The authors acknowledge the Managers of Oke-Odan and Sepeteri Irrigation Scheme of Ogun-Osun River Basin Authority; and Nigerian Metrological Agency (NIMET).

\section{Disclosure of conflict of interest}

The author declares no conflict of interest.

\section{References}

[1] Adeniran KA, Amodu MF, Amodu MO, Adeniji FA. Water requirements of some selected crops in Kampe dam irrigation project. Australian Journal of Agricultural Engineering. 2010; 1(4): 119-125.

[2] Broner I, Schneekloth J. Seasonal Water Needs and Opportunities for Limited Irrigation for Colorado Crops, Newsletter of the Extension Irrigation Services, Dept. of Civil Engineering, Colorado State University. 2013; 4: 718.

[3] Broner. Colorado State University Extension agricultural and bioresource engineering fact. 2005; 4: 708.

[4] Cazanescu S, Maracineanu F, Constantin E. Software Application for Irrigation Water Management Optimization. Research Journal of Agricultural Science. 2009; 41(2): 78-96.

[5] FAO (Food and Agriculture Organization). Cropwat: A Computer Program for Irrigation Planning and Management: Irrigation and Drainage Paper. No. 45. FAO, Rome. 1992.

[6] FAO, (Food and Agriculture Organization). Irrigation water requirements, In: Irrigation Potential in Africa: A Basin Approach, Chapter 5, FAO Corporate Document Repository, FAO, Rome. 2005.

[7] Kenneth, K Tanji, Neeltje, C. Kielen. Agricultural Drainage Water Management in Arid and Semi-Arid Areas FAO Irrigation and Drainage Paper. 2003; 61.

[8] Olubode-Awosola 00, Idowu EO, Van Schalkwyk HD. Irrigation Projects Reform Case Studies: An Assessment of Projects' Performance. 2005.

[9] Smith MA, Monteith R, Pereira JL, Pereira LA, Perner A, Segreen A. Report on the Expert Consultants on Procedures for Revision of FAO Guidelines for Prediction of Crop Water Requirements, FAO, Rome, Italy. 1991.

[10] Yusuf KH. Assessment of Small Scale Irrigation Using Comparative Performance Indicators on two Selected Scemes in Upper Awash River Valley. Unpublished M.Sc. Thesis, Alemaya University, Ethopia. 2004. 